\title{
La justicia de paz y las transformaciones en el gobierno de la ciudad (Rosario, 1852-1872)
}

\author{
por \\ Evangelina De los Ríos ${ }^{1}$ \\ ISHIR-CONICET / CEHISO-UNR
}

\begin{abstract}
El artículo estudia las transformaciones que experimentó la figura de los jueces de paz en Rosario (Santa Fe, Argentina) entre 1852 y 1872. Se mostrará que estos cambios no respondieron a decisiones reglamentarias y judiciales, sino que deben ser pensados en el contexto de cómo se fue modificando la forma en que se gobernaba la ciudad. El objetivo que persigue esta investigación es examinar las redefiniciones de las funciones de estos jueces a partir de una reconstrucción del entramado de relaciones — politicas, judiciales, policiales, administrativas, etc.- en las cuales se hallaban insertos.
\end{abstract}

Palabras Clave: justicia de paz; gobierno; administración; Rosario; siglo XIX.

Cómo Citar Este Artículo / Citation: De los Ríos, Evangelina, "La justicia de paz y las transformaciones en el gobierno de la ciudad (Rosario, 1852-1872)", Revista de Indias, LXXXI/282 (Madrid, 2021): 503-536. https://doi.org/10.3989/revindias.2021.015.

\section{INTRODUCCIÓN}

El presente artículo propone analizar los cambios que experimentó la justicia de paz en la ciudad de Rosario entre 1850 y 1870. El proceso de conformación de la Confederación Argentina (1852-1861) primero, y el Estado Nacional, más tarde, conllevó profundos cambios políticos, económicos y sociales que impactaron a nivel local. Por más de tres décadas no

\footnotetext{
${ }^{1}$ eddelosrios@hotmail.com, ORCID iD: https://orcid.org/0000-0002-6937-5981
} 
había existido en el antiguo espacio rioplatense otra entidad estatal que no fuera la provincial ${ }^{2}$. Las provincias asumieron todas las atribuciones que les correspondían como estados independientes: tenían sus monedas, cobraban sus impuestos, establecían sus aduanas, dictaban sus propias leyes y constituciones, aunque delegaron en Buenos Aires el manejo de las relaciones exteriores. Esta provincia logró una clara preponderancia mediante una política económica de exclusivismo comercial a través del cierre de los ríos interiores. A inicios de 1850, algunos estados provinciales se enfrentaron militarmente al ejército porteño con el objetivo de poner fin a esta situación. Con la derrota porteña, en la batalla de Caseros (1852), las provincias iniciaron el proceso de la conformación de un nuevo sistema político en clave nacional $^{3}$.

En estos años Rosario jugó un papel central como articulador del espacio económico-mercantil. Una situación que modificó tanto su fisonomía urbana como su espacio institucional. Fue necesario equipar el territorio ${ }^{4}$ a través de una compleja variedad de instituciones (Jefatura política, Juzgado de 1era Instancia, Jefatura de policía, municipalidad) y agentes (jueces de paz, tenientes de jueces, alcaldes de barrio, policías, serenos, entre otros) con diferentes funciones en el gobierno de la ciudad. Una dinámica que redefinió el papel de los jueces de paz. El trabajo constituye una primera, aunque muy necesaria, aproximación al tema a través del cual se pretende responder algunas preguntas: ¿Qué rol ocuparon en el nuevo entramado de relaciones políticas que se tejió en la ciudad? ¿Eran jueces, auxiliares de justicia o funcionarios menores de la jefatura de policía?

En los últimos tiempos las líneas de encuentro entre gobierno, territorio y administración de la justicia se han multiplicado. Los aportes desde el

${ }^{2}$ Luego de varios intentos constitucionales frustrados (1819 y 1826), el sistema político instituido recayó en las provincias convertidas en estados soberanos. La firma del Pacto Federal (1831) otorgó la base para la creación de una Confederación de estados independientes que mantuvieron un mínimo de integración. La situación cambió con la conformación de la llamada «Confederación Argentina», aunque en realidad se trató de un estado federal más que confederal, tal y como se afirmó en la Constitución de 1853. Chiaramonte, 1993.

${ }^{3}$ La complejidad de este proceso requiere de un examen que excede los límites de este trabajo. Por lo tanto, remitimos a los estudios de Garavaglia, 2016 y Bragoni y Miguez, 2010.

${ }^{4}$ El concepto de «equipamiento político de un territorio» incluye las acciones de diversos agentes y de distintos tipos - que atienden a conseguir un resultado orientado por esta voluntad de ordenamiento - y las expresiones simbólicas o físicas que este accionar va imprimiendo tanto en el terreno como en la concepción de su relación con las instituciones políticas. Barriera, 2006: 378-279. 
campo de la historia social de la justicia han adquirido nueva vigencia siguiendo los pasos de viejos autores (M. Bloch, E. P. Thompson, M. Foucault $)^{5}$. Se realizaron significativos avances sobre las formas de administrar justicia durante el siglo XIX, en general, y el funcionamiento de la justicia de paz, en particular ${ }^{6}$.

En el marco de estudios sobre los agentes inferiores de justicia y gobierno, la figura de los jueces de paz ha cobrado vigor (donde aparecen también otros agentes los comandantes militares, los comisarios de campaña, los jueces pedáneos, los alcaldes de barrio). Numerosas investigaciones - sin desconocer las contribuciones de la historia del derecho y la historia institucionalhan revalorizado la dimensión de la experiencia práctica de la justicia mostrando cómo bajaba la normativa a la práctica cotidiana más cercana a la población y cómo operaron las soluciones aplicadas a la realidad local en los distintos momentos ${ }^{7}$. Para comprender la dinámica del poder político local, los análisis a ras de suelo de estos funcionarios fueron indispensables a la hora de componer un cuadro sobre el diseño de la administración de justicia ${ }^{8}$. Al mismo tiempo, importantes estudios prosopográficos contribuyeron en la construcción de los perfiles de quienes administraban justicia en estos territorios $^{9}$. Estos trabajos sirvieron de marco de referencia para hacer visible los vínculos (de parentesco, de compadrazgo, de comercio, etc.) y la circulación de favores, conocer la lógica que guiaba la designación de un funcionario y delinear las trayectorias institucionales ${ }^{10}$.

Diferentes estudios han profundizado en los jueces de paz del mundo rural como una figura central de gobierno y de justicia en la campaña surgida a

\footnotetext{
5 Algunos balances historiográficos en Barriera, 2010b. Candioti y Palacio, 2007. Tío Vallejo, 2011: 199-212.

${ }^{6}$ La experiencia de la justicia de paz puede constatarse en Brasil (Sampaio Silva, 2007: 266-285. Flori, 1986); España (Moreno, 1987. Cobos Gavela, 1989. Gascón Inchausti, 2006: 183-213). México (Castillo Hernández, 2011); Francia (Petit, 2002: 85-10; 2003. Métairie, 1994. Delaigue, 1995: 31-47). La historiografía rioplatense ha profundizado sobre la justicia de paz en diferentes espacios provinciales (Buenos Aires, Córdoba, Mendoza, Santa Fe) por lo que se buscará aprovechar las evidencias suministradas. Véase Garavaglia, 1997: 241-262. Banzato y Valencia, 2005: 211-235. Romano, 2004: 167-200. Beraldi, 2017: 1-22. Sanjurjo de Driollet, 2003: 129-143; 2010. Canedo, 2011: 675-702. Corva, 2001. Yangilevich, 2017: 73-94. Barriera, 2011: 213-226; 2014a: 235-252.

7 Fradkin, 2007; 2009. Barreneche, 2001. Salvatore, 2010.

${ }^{8}$ Un balance en Molina y Yangilevich, 2015.

9 Perfil de la justicia letrada: Piazzi, 2016: 372-399; 2017a: 53-74. Candioti, 2012: $287-$ 324. Yangilevich, 2018: 213-242.

${ }^{10}$ Garavaglia, 1999. Gelman, 2000: 7-31. Di Gresia, 2010. Reguera y Di Gresia, 2014: 103-128.
} 
partir de la disolución de los cabildos ${ }^{11}$. Sin embargo, el abordaje de la justicia de paz en el mundo urbano constituye todavía un tema poco explorado ${ }^{12}$. Este trabajo que versa sobre la micropolítica de la ciudad de Rosario constituye un mirador desde el cual examinar los procesos de conformación de la administración local y la incidencia de diferentes proyectos políticos que modificaron el esquema de gobierno de la ciudad.

El arco temporal parte de un posicionamiento metodológico que centra la atención tanto en los procesos de cambios institucionales y normativos que transformaron profundamente la justicia de paz como en el desenvolvimiento relacional de estos jueces dentro del entramado político de esos años. Se marca como punto de inicio el año 1852 con la designación de Rosario como ciudad. No obstante, la creación de la jefatura política (1854) representó un punto de inflexión de un proceso que acompaña numerosas modificaciones políticas, institucionales y normativas que contribuyeron a redefinir la administración local, la estructura institucional y el diseño judicial en que se movían los jueces de paz ${ }^{13}$. Para 1872 la reforma de la Constitución provincial contempló un nuevo régimen de Municipalidades mediante el cual la designación de los jueces de paz, ya no se efectuaría a instancia del jefe político, sino mediante elecciones a través del voto de los vecinos.

\section{Metodología y fuentes}

Para esta investigación se consultaron materiales provenientes de diversos acervos. Los decretos sobre la organización administrativa y judicial de Rosario se encuentran compilados en el Registro Oficial de Santa Fe (en adelante ROSF) donde figuran también los nombramientos de los diferentes empleados de la administración provincial entre los que se encuentran los jueces de paz. El Archivo de la Legislatura Provincial (en adelante ALP) cuenta con fuentes de suma riqueza. En el mismo constan los distintos proyectos presentados a la Legislatura - tanto aquellos que quedaron en el papel como los efectivamente ejecutados - así como las transcripciones de los debates que se sucedían al interior del recinto durante cada sesión. El acceso a este material permite estudiar las propuestas en torno a la organización de la justicia

\footnotetext{
11 Véase Ternavasio, 2000a: 295-336

12 Un interesante estudio sobre el tema en Gastellu, 2018: 263-290.

13 Barriera, 2010a.
} 
de paz en Santa Fe y de qué manera fue pensada — y repensada - la figura de estos jueces en los diferentes ordenamientos.

Una parte importante de la documentación proviene del fondo Jefatura Política del Archivo del Museo Histórico Provincial de Rosario «Dr. Julio Marc» (en adelante AHPJM). La pesquisa se centró en los legajos denominados: Jueces de paz de la ciudad, Jefatura politica de Rosario, Jefatura de policía, Juzgado de 1. ${ }^{a}$ Instancia y fojas sueltas englobadas bajo la signatura Documentos varios o Borradores. Se tratan en su mayoría de correspondencia que circulaba entre las diferentes oficinas de la administración. Estos legajos aportan información de primera mano sobre las situaciones más cotidianas que se sucedían en torno a las oficinas departamentales: las quejas y las frustraciones de los empleados, las dificultades a la hora de emprender sus tareas, las formas en que se tejían las relaciones entre los diferentes empleados y entre estas autoridades con los demás vecinos del departamento revelando algunos destellos de la vida local.

\section{LA JUSTICIA DE PAZ EN ROSARIO Y SU TRANSFORMACIÓN DE VILLA A CIUDAD}

En 1819 mediante la aprobación del Estatuto provisional comenzó a gestarse una nueva configuración administrativa y se delineó, todavía de manera incipiente, la división de la provincia en un departamento cabecera, La Capital, y tres «departamentos de campaña», los antiguos partidos de Pago de los Arroyos - luego departamento Rosario-, Coronda — también llamado San Gerónimo- - y Rincón — San José— ${ }^{14}$. El departamento Rosario, una de las cuatro circunscripciones en que se dividía la provincia de Santa Fe, ocupaba una franja que se extendía de sur a norte desde el Arroyo de Medio, línea divisoria con la provincia de Buenos Aires, hasta el Arroyo Carcarañá, límite con el departamento de San Gerónimo. Mientras que al este el río Paraná demarcaba claramente la jurisdicción, hacia el oeste la delimitación era más compleja, ya que hasta fines del siglo XIX no se acabaron de esclarecer los límites provinciales ${ }^{15}$. El departamento contaba con un centro urbano como cabecera, Rosario, y numerosos distritos de campaña cuyos nombres se correspondieron, en general, a los cursos de agua casi perpendiculares al río

${ }^{14}$ El término departamento significa actualmente: división de un territorio sujeta a una autoridad administrativa. En Santa Fe este término comenzó a ser utilizado en el Estatuto Provincial de 1819 relegando poco a poco el término «partido», eliminado definitivamente del vocabulario administrativo luego de 1833.

15 De los Ríos, 2017. 
Paraná que recorrían la provincia (Arroyo Seco, Pavón, Cañada de Cabral, Ludueña).

La supresión del Cabildo santafesino desde 1833 transformó la políticainstitucional santafesina y plasmó entonces una nueva distribución del poder que venía gestándose desde $1819^{16}$. Con su disolución la provincia perdía la única institución secular que había sido sede de la justicia, por lo que se procedió a la reorganización de las instituciones judiciales ${ }^{17}$.

La justicia de paz se instituyó en la provincia de Santa Fe en 1833 a partir de la sanción del Reglamento provisorio para los empleados y atribuciones que deben subrogarse el cuerpo municipal.... El Reglamento venía a llenar el vacío que dejó la supresión del Cabildo el año anterior. Se designó un Juez de 1. ${ }^{\mathrm{a}}$ Instancia en lo Civil y Criminal, un Defensor de pobres y menores, y un Juez de Policía, con jurisdicción en toda la provincia. Se nombró también un juez de paz para cada uno de los cuarteles en los que se dividía la ciudad de Santa Fe y otro para las Chacras, con carácter de carga pública. En los denominados departamentos de campaña los alcaldes de hermandad y jueces pedáneos fueron reemplazados por jueces de paz y comisarios de distrito ${ }^{18}$. Mientras las atribuciones de aquellos estuvieron orientadas a preservar el orden de la población, gestionar la seguridad e imponer medidas de moralidad, la nueva figura judicial que lo reemplazó, el juez de paz, concentró amplias atribuciones además de las judiciales: la civil, la criminal, la comercial y la de policía ${ }^{19}$. Tenía jurisdicción ordinaria sobre todo el departamento, es decir pueblo y campaña. Para ejercer el control sobre su territorio poseía la potestad de nombrar el número de comisarios que se considerase necesario tanto para el pueblo - aunque de antemano se estipularon dos comisarios para Rosario - como para la campaña, según «los que su población y circunstancias exigieren $\rangle^{20}$.

Por lo tanto, hasta 1852 las máximas autoridades de Rosario eran el Juez de Paz y el Comandante Militar, figura clave de la organización militar

16 Sobre la supresión del cabildo en las diferentes provincias: Ternavasio, 2000b: 33-73. Barriera, 2014: 235-252; 2016: 427-450. Tedeschi, 1993. Agüero, 2012: 43-84.

17 Santa Fe no había contado nunca con una audiencia. Sobre las implicancias de la disolución del Cabildo, véase Barriera, 2011: 213-226.

18 Sobre la justicia colonial: Barriera, 2013a: 1-31; 2013b: 137-167. Tornay, 2004.

19 Sobre la justicia de paz en Santa Fe: Ensinck, 1963: 5-25. Barriera, 2011: 213-226; 2014a: 235-252; 2017a:289-312.

${ }^{20}$ Reglamento provisorio para los empleados y atribuciones que deben subrogar al Cuerpo municipal, extinguido por ley de 13 de octubre del año próximo pasado de 1832, 28 de enero de 1833, Registro Oficial de Santa Fe, Santa Fe (ROSF), tomo I: 243. 
provincial ${ }^{21}$. Con la supresión de la Comandancia Militar del departamento - pocos meses antes se habían eliminado las de San Gerónimo y de San José—22, el juez de paz asumió, además de la judicatura civil que hasta el momento ejercían, lo que correspondía a las comandancias militares y de policía ${ }^{23}$.

Durante los años 1850 y 1860, la villa del Rosario sufrió una profunda transformación en su fisonomía urbana que requirió la creación de nuevas instituciones. El proceso iniciado luego de la caída de Juan Manuel de Rosas y la construcción de un poder que operaba a nivel nacional, la Confederación Argentina, impactó en el espacio local. En este contexto, Rosario jugó un papel central como articulador del espacio económico-mercantil que permitió su vinculación directa con los mercados extranjeros y amplió su participación en los circuitos comerciales con las restantes provincias interiores ${ }^{24}$. En vista de la nueva posición que ocupaba y la importancia de su puerto, que se había convertido en uno de los ejes fundamentales dentro en el ámbito económico y financiero para el estado central, Justo José de Urquiza (1852), el nuevo director provisorio de la Confederación Argentina, solicitó al gobernador de Santa Fe que elevará el rango de Rosario de villa a ciudad ${ }^{25}$. La Junta de representantes de la provincia decidió respaldar esta decisión y aprobó la propuesta $^{26}$.

La reactivación del comercio transformó a la otrora villa en una ciudad en la que se contaban más de doscientas casas de negocios, un número considerable de bancos, diversos periódicos, mercados, tiendas, hoteles e importantes instituciones financieras y crediticias ${ }^{27}$. El proceso de expansión económica fue acompañado por un fuerte crecimiento demográfico. Si para

${ }^{21}$ En Santa Fe, la organización militar estuvo bajo la figura del comandante general de Armas, con mando directo sobre las tropas de la capital y tres comandantes militares, uno por cada departamento (a saber, San Gerónimo, San José y Rosario). R. Fradkin ha señalado la importancia del estudio de la figura de los comandantes militares «personajes tan claves como difusos». Fradkin, 2010: 297: 293-306.

22 Decreto suprimiendo las Comandancias militares de San Gerónimo y San José, y nombrando Gefes para estos Departamentos, 8 de mayo de 1852, ROSF, tomo II: 93-94.

${ }_{23}$ Decreto suprimiendo la Comandancia militar del departamento del Rosario, 21 de diciembre de 1852, ROSF, tomo II: 127.

${ }^{24}$ Véase Gallo, 1965: 127-161. Ensinck, 1971: 1-50. Frid, 2011: 95-138; 2012: 17-48. Bonaudo, 2006.

${ }_{25}$ Santa Fe, 22 de junio de 1852, Archivo de la Legislatura Provincial, Santa Fe (ALP), Cámara de Diputados, tomo 1: 128.

${ }^{26}$ Ley erigiendo a la categoría de ciudad la villa del Rosario, 3 de agosto de 1852, ROSF, tomo II: 110.

27 Álvarez, 1998: 337. 
1851, Du Graty estimaba que en Rosario habitaban aproximadamente tres mil personas, el censo de la Confederación (1858) mostró que la ciudad contaba con al menos 9.587 habitantes y, una década más tarde, el primer Censo Nacional (1869) estableció que la población alcanzó los $23.169^{28}$ y tuvo su correlato en la expansión de su planta urbana que llegó a ocupar unas cincuenta manzanas ${ }^{29}$.

En este contexto de fuerte crecimiento demográfico y urbano, las quejas de estos jueces por la sobrecarga de trabajo, las continuas negativas de los vecinos a aceptar los nombramientos y la renuncia de los designados obligaron a las autoridades provinciales a recortar algunas competencias que se encontraban bajo su órbita. La instalación un Juzgado de Policía representó un primer paso $^{30}$. Sólo había un Juez de policía, en la ciudad de Santa Fe, que tenía jurisdicción sobre toda la provincia. A partir de su nombramiento en Rosario, este asumió las funciones estipuladas en el Reglamento de 1833, a saber: conservar el aseo en las calles con los reos destinados al servicio público; garantizar uso correcto del alumbrado; vigilar que no quedasen carretas o animales de noche en la calle; controlar el nivel de las aguas; supervisar las edificaciones y las obras públicas; revisar las pesas (abasto de carne, pulperías, tiendas); sancionar penas o multas haciéndolas públicas mediante carteles; asistir a mensuras, deslindes y remates judiciales; intimar embargos de bienes; aprehender a personas por orden escrita; llevar un libro con los aprehendidos y embargos; cuidar la seguridad de la prisión y el cumplimiento de su funcionamiento (horarios de desahogo de presos, órdenes de libertad) ${ }^{31}$.

${ }^{28}$ El departamento Rosario era el más poblado de la provincia, contaba con casi el $50 \%$ de la población (unas 22.492 personas). El 42 \% vivía en la ciudad de Rosario y el resto en los diferentes distritos de campaña. Registro Estadístico..., 1858. Para 1869 la población del departamento había alcanzado los 47.730 habitantes, 23.169 se hallaban en Rosario y la restante población se distribuían en los dos nuevos núcleos urbanos — San Lorenzo (3.274) y Villa Constitución (1.895) - y los distritos de campaña (19.392). Primer Censo ..., 1869.

${ }^{29}$ El censo de 1858 mostraba que en Rosario existían apenas 19 casas de azotea y alto, 530 de azotea, 10 de tejas mientras que 758 eran de paja y 411 eran ranchos. Para 1869 las casas de azotea y alto alcanzaron los 67, se triplicó el número de casas de azotea (1.607), las casas de pajas pasaron a ser 3.775 y se crearon además 231 casas de madera. Registro Estadístico..., 1858; Primer Censo..., 1872.

${ }^{30}$ Ley creando un Juzgado de Policía en la ciudad del Rosario. Sólo una persona ejerció con este nombre la autoridad policial en Rosario y fue el teniente coronel Estanislao Zeballos durante el transcurso del año 1853, con un sueldo de $600 \$$ anuales. Decreto nombrando varios empleados, 28 de diciembre de 1852, ROSF, tomo II: 129 y 191.

${ }^{31}$ Reglamento provisorio para los empleados y atribuciones que deben subrogar al Cuerpo municipal, extinguido por ley de 13 de octubre del año próximo pasado de 1832, 28 de enero de 1833, ROSF, tomo I: 247-249. 
En 1853 se estableció también una Comisaría General del departamento. El Decreto reeditaban una vez más los mismos argumentos utilizados para crear el Juzgado de Policía: la sobrecarga de funciones del Juez de Paz, que complicaban la administración de justicia y la expedición de los asuntos judiciales, por una parte, y la negativa de los vecinos para ocupar el cargo, por otra ${ }^{32}$. El Comisario General quedó bajo las órdenes del juez de paz, pero tenía atribuciones propias determinadas en una serie de artículos que acompañaron la disposición. Las mismas versaban sobre cuestiones referentes a las tropas veteranas o de milicias, de ciudad y fronteras (suministrar raciones, distribuir los sueldos y gratificaciones recibiendo un recibo a cambio para entregar al administrador de Aduana, corroborar estas listas y remitirlas al gobierno, encargarse de las obras públicas). Además, podía pedir, en nombre del Gobierno, colaboración a comerciantes y particulares para surtirse de artículos, contratar reses para el consumo de las tropas y atender su envío, cuidar los cueros del Estado, recoger las gorduras de las reses del consumo, proveer de velas a las oficinas de la administración, entre otras cosas. En muchos sentidos la figura del Comisario General venía a cumplir algunas de las antiguas tareas que desempeñaban los Comandantes Militares.

Para 1853 la administración de Rosario estaba precedida por el juez de paz quien tenía bajo su dependencia tanto al juez de policía y sus comisarios como al juez de comercio ${ }^{33}$. También debían controlar las oficias de hacienda integrada por la receptoría departamental, la aduana y el resguardo de puerto que, aunque en la letra estaban bajo el control del gobierno nacional, permanecieron en la esfera provincial hasta $1855^{34}$. Respondían ante el juez los comisarios de cada distrito rurales y el Comisario General de Campaña.

32 Decreto estableciendo en la ciudad del Rosario una Comisaría general, 17 de noviembre de 1853, ROSF, tomo II: 170 .

33 Para 1853 se nombró a Tiburcio Aldao como juez de comercio para los departamentos de La Capital, San Gerónimo y San José, y a Antonio Berdier para Rosario. Decreto nombrando varios empleados, 28 de diciembre de 1852, ROSF, tomo II: 132. Y para 1854 se designó para Rosario a Belisario Ortiz. Decreto nombrando varios empleados, 20 de diciembre de 1853, ROSF, tomo II: 177.

${ }^{34}$ De los Ríos, 2019: 24-46. 
Diagrama 1. La ADMinistración de La CIUdAd de Rosario (1853)

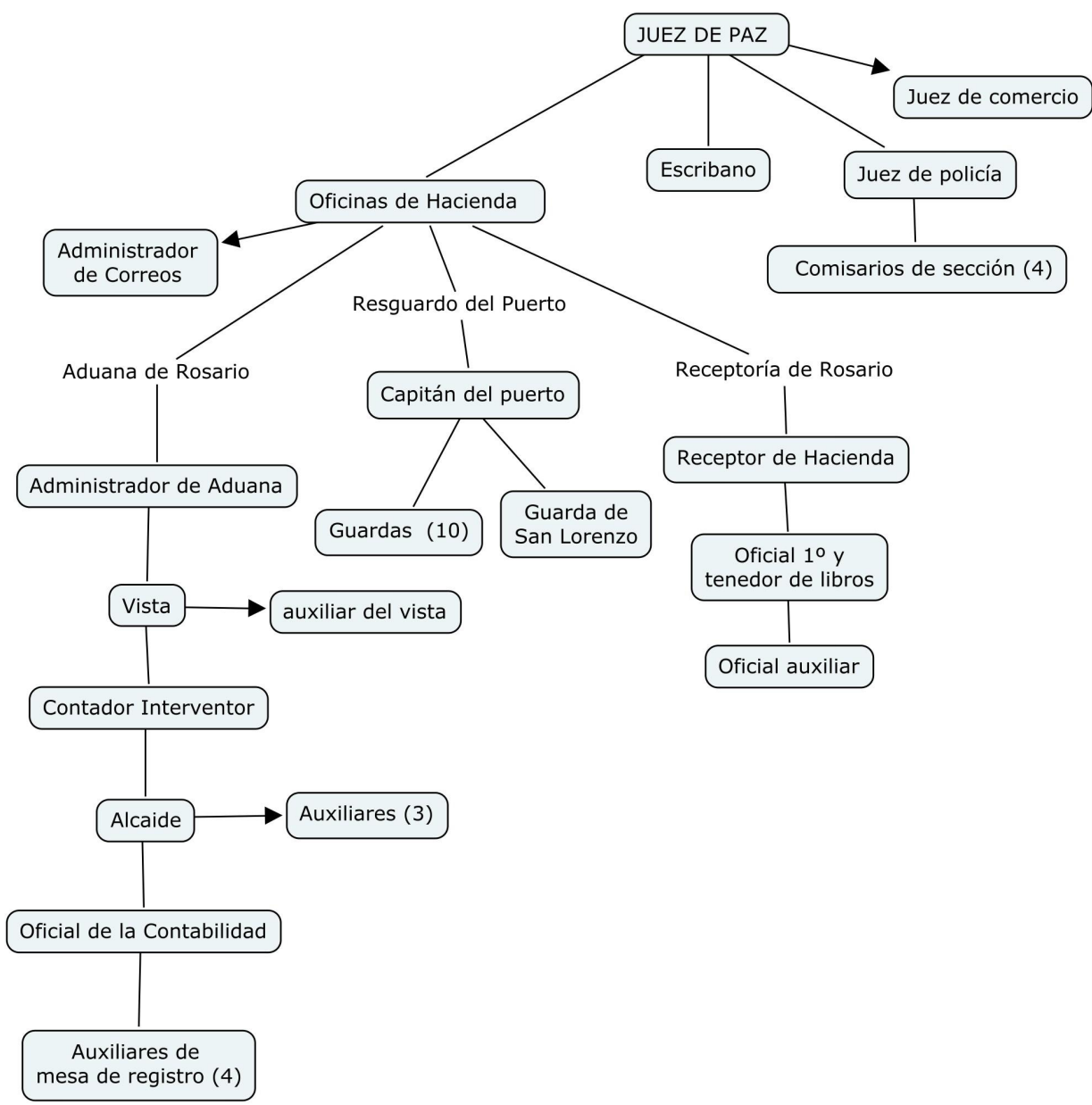

Fuentes: elaboración propia en base al Registro Oficial de Santa Fe.

El presente diagrama contempla la organización administrativa de la ciudad de Rosario. No tiene en cuenta la campaña. Tampoco se mencionan: la banda de música militar y el personal que integraba la instrucción pública.

UNA NUEVA FORMA DE GOBERNAR LA CIUDAD: LA JEFATURA POLÍTICA DE ROSARIO

A partir de la elevación de Rosario a ciudad — un proceso atravesado por fuertes cambios políticos económicos y sociales - fue necesario confeccionar un nuevo armazón político-institucional para gobernar este territorio. En 1854, 
Nicasio Oroño ${ }^{35}$ dirigió una carta al presidente de la Confederación, Justo José de Urquiza, en la que expresaba:

Cuando esta ciudad era apenas una villa de campaña, pudo ser gobernada por un juez de paz, pero hoy que se ha hecho una ciudad de importancia [...]; hoy que su puerto y su aduana son nacionales debiendo venir aquí a proveerse de mercancías las provincias interiores de la confederación, y que esta ciudad es también el asiento de la principal sucursal del banco nacional, es un delirio creer que pueda continuar el antiguo estado de $\cos ^{36}{ }^{36}$.

La idea de N. Oroño consistía en establecer en la ciudad una Jefatura Política. Una propuesta que tuvo fuerte eco entre las autoridades nacionales que ejercieron presión sobre las autoridades provinciales para que, poco más tarde, aprobaran el proyecto. El 30 de julio de 1854 se instituyó una nueva organización política y administrativa para Rosario cuya cabeza era la Jefatura política. El juez de paz fue reemplazado como máxima autoridad política del departamento por un Jefe político ${ }^{37}$. Este, nombrado por el Poder Ejecutivo, debía: ejecutar y hacer que se ejecute en el departamento — ciudad y campaña - las diferentes leyes, decretos y disposiciones; mantener el orden; proteger personas y propiedades; reprimir y castigar toda afrenta a la religión, la moral o la decencia pública, así como también cualquier desobediencia o falta de respeto a su autoridad; imponer penas correccionales y someter a la acción de los tribunales de justicia. Cada jefatura se convirtió en la cabeza visible de una compleja red administrativa, política y policial que comprendía un conjunto jerarquizado de funcionarios que formaban parte de diferentes oficinas (policías, administradores, jueces, etc.) ${ }^{38}$.

${ }^{35}$ Nicasio Oroño era un político y militar de trayectoria muy destacada de la provincia de Santa Fe. Fue un hombre de confianza de J. J. de Urquiza con quien mantuvo estrechos vínculos comerciales. Durante la campaña contra Rosas se lo nombró Teniente de la división santafesina para pelear la batalla de Caseros. Ascendido a Capitán y actúo como secretario de su padre, designado Comandante militar de los departamentos Rosario y San Gerónimo. Sus vínculos con las autoridades nacionales lo convirtieron en administrador de la Aduana y contador y presidente interino de la Administración de Hacienda y Crédito Público. En 1855 ocupó el cargo de jefe político de Rosario y fue diputado nacional (1862), gobernador de la provincia (1865-1868) y senador por Santa Fe (1868 a 1876). Cutolo, 1968: 194-195.

${ }^{36}$ Carta de Nicasio Oroño al Exmo Presidente de la Confederación, Capitán General Don Justo José de Urquiza, 1 de junio de 1854, citado en Carrasco, 1897: 293.

37 En 1863, se creó una Jefatura para La Capital y San José. Éste último se independiza en 1868, mientras que en 1866 se creó la Jefatura Política en Coronda (San Gerónimo). Véase Bonaudo, 2003: 259-276; 2008: 255-280.

${ }^{38}$ Decreto organizando administrativa y judicialmente el pueblo y departamento del Rosario, 30 de julio de 1854, ROSF, tomo II: 213-214. Un análisis detallado de las jefaturas políticas en distintos espacios provinciales en Piazzi, $2017 \mathrm{~b}$. 


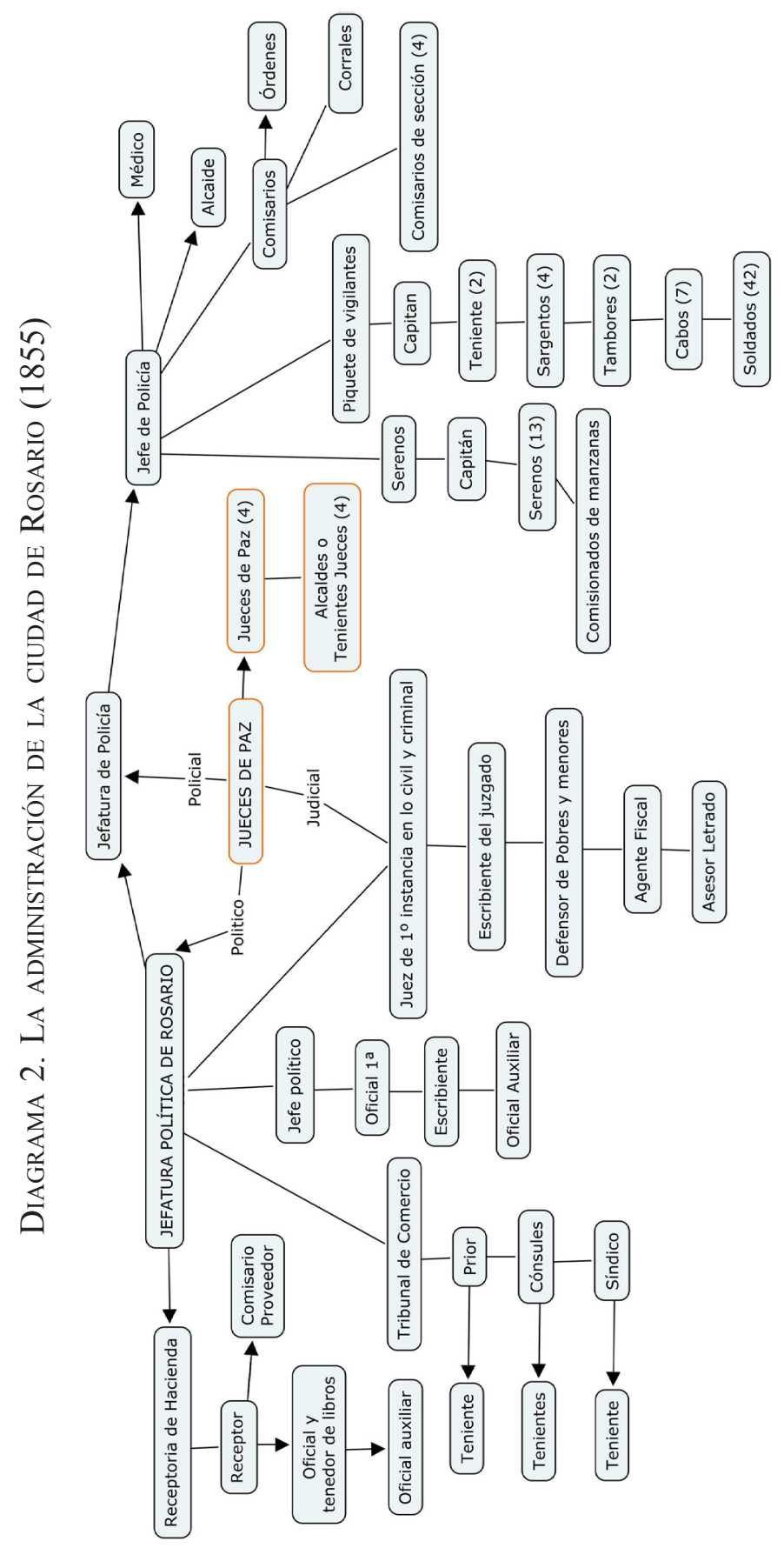

ठ
है
है เี่

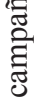

점

苞

담

.

乙․ ฮ่

으

预

으:웅

\&

믐

.

ن 준

空

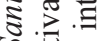

ช

จ

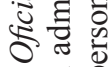

응 $\frac{2}{0}$

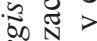

尺े है

젛히

สี 즈 저

ฮ 준.

풀,

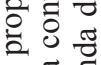

:을 ฮี

해요

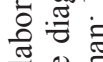

ब

$\ddot{0} \overline{0}$

可至至

Revista de Indias, 2021, vol. LXXXI, n. ${ }^{\circ}$ 282, 503-536, ISSN: 0034-8341

https://doi.org/10.3989/revindias.2021.015 
El jefe político tenía bajo su dependencia al jefe de policía y como auxiliares a los jueces de paz y tenientes alcaldes, en la ciudad, y a todos los comisarios de distrito, en la campaña. Debía además supervisar el funcionamiento de las oficinas de receptoría de hacienda departamental y el Tribunal de Comercio de Rosario ${ }^{39}$.

El ordenamiento administrativo de la ciudad tuvo su correlato en la forma que se administró el territorio ${ }^{40}$. La ciudad se dividió en cuarteles (en un principio cuatro y más tarde seis) y al frente de cada uno se nombró un juez de paz. Como se observa en el diagrama 2, el papel de los jueces de paz de Rosario se redefinió y limitó su accionar a los cuarteles. Estos se transformaron en auxiliares de la Jefatura política, aunque dependía de los Jueces de 1ra. Instancia en la judicial, del jefe de policía en lo policial y del receptor de hacienda en lo fiscal. Contaban con el auxilio de tenientes jueces - también llamados tenientes alcaldes - para el desempeño de sus funciones quienes debía juzgar en la esfera de las atribuciones inherentes al juez de paz cuando este estuviera impedido de hacerlo a fin de no retardar demandas y evitar males o escándalos; ejercer el cargo en ausencia, enfermedad o fallecimiento del juez. Podían entender y definir demandas por debajo de 5 , oír y juzgar en todo otro asunto que evite desordenes o escándalos en su cuarte ${ }^{41}$.

El Decreto organizando administrativa y judicialmente el pueblo y departamento de Rosario (1854) dedica un capítulo (capítulo V) a la forma de elección de los jueces de paz y sus auxiliares, los tenientes alcaldes o tenientes jueces. El Reglamento de Justicia (1833) no había estipulado cómo eran las designaciones - aunque si mencionaba que los cargos tendrían una duración de un año, al cabo del cual debía resolverse su renovación-, por lo cual su inclusión en este Decreto brinda algunas precisiones: se estipuló que los jueces serían nombrados por el Poder Ejecutivo de la provincia en base a una terna que el Juez de 1ra. Instancia elevaba al Jefe político ${ }^{42}$. Pese a ello, una mirada a la correspondencia entre Jefe Político y jueces de paz deja ver que era habitual que al juez saliente confeccionara la propuesta e incluso, en al-

39 El Tribunal de Comercio se creó en 1854 y reemplazó en sus funciones al juez de comercio. El tribunal quedó conformado por un prior, dos cónsules, dos tenientes cónsul y un teniente síndico, elegidos entre ciudadanos matriculados en el registro de comerciantes de la ciudad. Decreto organizando administrativa y judicialmente el pueblo y departamento del Rosario, 30 de julio de 1854, ROSF, tomo II: 215.

40 Aliatta, 1998: 199-254.

${ }^{41}$ Deslindando las atribuciones del teniente de juez de paz, 22 de enero de 1853, ROSF, tomo II: 136.

42 Decreto organizando administrativa y judicialmente el pueblo y departamento del Rosario, 30 de julio de 1854, ROSF, tomo II: 216. 
gunos casos, recomendara directamente a su sucesor o informara el interés de algún vecino por asumir el cargo ${ }^{43}$.

Si bien se avanzó sobre los modos de preceder a la elección, no se estipularon cuáles eran los criterios que debían utilizarse ni las condiciones que debían reunir los candidatos. Sin embargo, una y otra vez se reiteraron ciertas fórmulas que resaltaban algunas cualidades como «su patriotismo, de su amor al orden y engrandecimiento de su país natal...» ${ }^{44}$. Para tener una imagen más nítida de estos atributos se requiere un estudio exhaustivo que permita reconstruir íntegramente su perfil social. Un primer acercamiento nos muestra que estos fueron, en general, personas influyentes en lo local que tenían experiencia en el manejo de asuntos económicos ${ }^{45}$. Eran casi en su totalidad comerciantes, tenderos, negociantes, es decir, personas con fuertes intereses en la ciudad. Se esperaba que vivieran en el cuartel para el que eran nombrados y, por lo tanto, conocieran de primera mano su composición y a sus vecinos, ya que se estimaba que la equidad sólo podría devenir de su conocimiento local y sus vínculos con la población y el territorio ${ }^{46}$. Investigaciones actuales sobre la baja justicia han mostrado que en los escalones más bajos de la administración se valoraba más su proximidad — que no era sólo geográfica, sino también cercana en lo social, lo simbólico, lo administrativo y en sus prácticas procesales y lenguajes jurídicos - respecto a la comunidad sobre la que debían actuar ${ }^{47}$.

Un cambio significativo - que revela el lugar que ocuparon entonces estos jueces de paz de ciudad - lo marca el hecho de que a partir de la

${ }^{43}$ La elevación de una propuesta era común en casos de renuncia donde se dejaba asentado el posible reemplazo, que era, por lo general, aceptado. Jueces de paz de la ciudad, 23 de abril de 1855, Archivo del Museo Histórico Provincial de Rosario «Dr. Julio Marc», Rosario (AHPJM), Jefatura Política, tomo único, n. ${ }^{\circ} 16$, s/f.

${ }_{44}$ Borradores, 28 de febrero de 1855, AHPJM, Jefatura Política, tomo $1855 \mathrm{~A}, \mathrm{n} .^{\circ} 3$, s/f.

${ }^{45}$ Los estudios realizados para el caso de la provincia Buenos Aires han mostrado que los jueces de paz no eran necesariamente los propietarios más ricos, sino que este cargo recayó en pequeños o medianos propietarios y, en algunos casos, pequeños comerciantes. Véase Garavaglia, 1999. Gelman, 2000: 7-31.

${ }_{46}$ Actualmente me encuentro desarrollando un proyecto postdoctoral bajo el título «Jueces de paz en el mundo urbano. Trayectorias políticas y prácticas judiciales. Rosario, 1854-1872».

${ }^{47}$ La proximidad no se refiere únicamente a la cercanía geográfica, aunque a primera vista esta aparece como más real y objetiva, se halla integraba de otros elementos: las distancias material, simbólica, procesal, social y administrativa. El concepto de distancia en la historiografía francesa en Metieri, 2006 y Petit, 2003. Nuevos abordajes han contribuido a ampliar la mirada: Barriera, 2012a: 50-57; 2012b: 1-28. Molina, 2014. Polimene, 2014: 157-176. 
creación de la Jefatura política dejaron de percibir salarios. Si bien el Reglamento de Justicia de 1833 estipulaba un sueldo de 100 \$ anuales para el juez de paz de Rosario ${ }^{48}$ (sueldo que fue reajustado a lo largo de los años siguientes alcanzando los $300 \$$ anuales para $1852^{49}$ y duplicándose a $600 \$$ anuales en $1854^{50}$ ), la conversión en justicia de menor cuantía revistió a los nombramientos con carácter de carga pública, ad honorem, aunque como compensación por sus tareas se creyó justo que la mitad de lo producido por el cobro de multas y sellos, la recaudación de algunos impuestos o el pago de las contravenciones se destinase a cubrir ciertos gastos de escritorio y gratificaciones a las personas que se ocupaban en el servicio del juzgado ${ }^{51}$.

Las discusiones sobre la percepción o no de salarios, por un lado, y la concepción de lo que representaba un «salario justo» constituyeron dos puntos de controversia que atravesó a toda la administración provincial. ¿Cuánto podía exigirse a empleados que no cobraban sueldos por sus tareas? ¿Quiénes aceptaría ocupar estos puestos? Estas preguntas se constituyeron una caja de resonancia y representaron cuestiones que las autoridades provinciales debieron resolver. Así en las sesiones legislativas de 1862, un proyecto de ley sobre la organización del Poder Judicial de Santa Fe despertó fuerte controversia ya que se estipulaba que todos los integrantes del Poder Judicial permanecerían tres años en sus puestos. Se oyeron voces disonantes que solicitaron modificar la propuesta en los escalones más bajos remarcando que «el empleo de juez de paz era una carga bastante pesada, que se servía gratis, y que no debía obligarse por tanto tiempo a empleados

${ }^{48}$ En su trabajo sobre la justicia de paz en la primera mitad del siglo XIX, D. Barriera señala que existió una jerarquía entre los territorios expresada en la diferencia salarial de los jueces. Mientras que el juez de paz de Rosario debía atender a un poblado de 6.000 personas, en Coronda la población apenas alcanza a las 2.200 y el Rincón rondaba las 800 , lo que justificaba que el sueldo del de Rosario fuera el doble del asignado a su par de Corona, quien percibía 50 \$ anuales. Y el de Rincón no percibía nada. Barriera, 2011: 213-226.

49 El incremento del sueldo mantuvo las diferencias entre los jueces de paz de los diferentes departamentos: el de Rosario pasó a cobrar 300 \$ anuales, mientras que el de San Gerónimo y San José cobraron apenas 100 \$. Proyecto de ley sobre sueldo de los empleados, 1 de marzo de 1852, ALP, Cámara de Diputados, tomo 1: 49-50.

50 Sanción Legislativa asignando sueldo al juez de Paz y al Juez de Policía del Rosario, 18 de enero de 1854, ROSF, tomo II: 191.

${ }^{51}$ Instrucciones de politica por los jueces de paz, 24 de febrero de 1858, AHPJM, Jefatura Política, tomo $1858 \mathrm{~A}, \mathrm{n} .^{\circ}$ 9, s/f. Una situación análoga ocurría con los comisarios de distrito. Véase De los Rios, 2017. 
que no gozaban de sueldo» ${ }^{52}$. Finalmente se resolvió que los oficiales de justicia permanecieran tres años «con excepción de los jueces de paz, tenientes jueces y empleados subalternos de cada oficina» que sólo estarían un año en sus puestos ${ }^{53}$.

En 1867, las discusiones en torno al salario de los jueces se zanjaron a través de un derecho que estipuló que los jueces de los cuarteles de Santa Fe y de Rosario a partir del $1^{\circ}$ de enero de año siguiente comenzarían a percibir un sueldo. No obstante, se consideró que el número de jueces de paz en ambas ciudades era excesivo y el fisco no cubriría un incremento de salarios. Se modificó entonces la distribución de los cuarteles: la primera quedó dividida en tres cuarteles mientras que la segunda pasó de seis a cuatro. Por lo tanto, el número de jueces de paz se redujo de doce a siete, aunque se propuso compensar esta pérdida asignando dos tenientes a cada juez ${ }^{54}$.

LOS JUECES DE PAZ ¿ JUECES, FUNCIONARIOS MENORES DEL JUSTICIA O AUXILIARES DE LA JEFATURA DE POLICÍA?

El decreto para la organización administrativa y judicial de Rosario no sólo redefinió el lugar de los jueces de paz en el esquema político también modificó sus competencias judiciales y policiales debido la instalación de la Jefatura de Policía y el Juzgado de 1 . $^{\mathrm{a}}$ Instancia en lo civil y criminal ${ }^{55}$. Hasta 1854 , en lo que respecta a la esfera judicial, el juez de paz, entonces la única autoridad judicial sobre el territorio, era el encargado de la aprehensión, toma de declaración y prisiones de los delincuentes. Podían oír y sentenciar en forma verbal todas las demandas desde $25 \$$ hasta $100 \$$ dando resoluciones que hicieran al orden y a la tranquilidad de los territorios bajo su dependencia. Además, dictaminaba sobre demandas escritas de más de $100 \$ \$^{56}$. Tenían facultad de arrestar, hasta el término de ocho días, a los que no cum-

52 Discusión sobre el Reglamento de Justicia, 3 de septiembre de 1862, ALP, Actas Legislativas, fs. $164 \mathrm{v}$.

53 Ley organizando el Poder Judicial, 21 de julio de 1864, ROSF, tomo IV: 174.

${ }^{54}$ Decreto dividiendo en tres cuarteles la Capital y en cuatro la ciudad de Rosario, 12 de diciembre de 1867, ROSF, tomo VI: 76.

55 Para un estudio en detalle de la justicia letrada en Rosario remito a Piazzi, 2011.

${ }^{56}$ Los jueces de paz de Coronda tuvieron idénticas funciones, aunque sólo los jueces de paz del departamento de Rosario podía llevar adelante procesos escritos. El juez de paz de Rincón y los comisarios de los distritos de campaña podían oír y sentenciar demandas verbales hasta la cantidad de $25 \$$ y ejecutar arrestos o prisión por el término de ocho días, así 
pliesen su mandato ${ }^{57}$. Cuando su jurisdicción se redujo a los cuarteles de la ciudad pasaron a cumplir idénticas funciones judiciales que sus pares de la ciudad de Santa Fe, es decir sólo podía oír y sentenciar verbalmente toda demanda por deuda u de otra clase hasta la cantidad de $25 \$$, ejecutar arrestos y prisión por el término de ocho días y conceder apelación en jurisdicción superior a $6 \$$. Su tarea principal era la resolución de orden de la familia y tranquilidad del cuartel «tenían acción, y deber de cortar por vías suaves, cualquiera desatención ruidosos o que turbe el orden público en cualquiera hora del día y de la noche, en el distrito de su cuartel y a una cuadra al frente de su morada, o de otro, sino vive en ella el que le corresponde». En caso de no surtir efecto la vía suave estaban autorizados a hacer uso de la fuerza - contando con la colaboración de los vecinos de su dependencia o con la partida celadora, quienes debían auxiliarlos-y decretar el arresto o la prisión, según la gravedad del asunto ${ }^{58}$.

La creación de un nuevo Reglamento de Justica (1861) estableció que todos los jueces de paz eran «auxiliares de los jueces de 1. ${ }^{a}$ Instancia del departamento judicial». Sin embargo, al igual que Reglamento de Justicia de 1833, marcó diferencias entre los jueces de paz de las ciudades de Santa Fe y de Rosario y aquellos de los pueblos y colonias (a saber, San Gerónimo, San José, San Lorenzo, Villa Constitución, colonia de Esperanza y Colonia San Carlos $)^{59}$. Mientras los jueces de paz de los pueblos y colonias conocían en segunda instancia las causas determinadas por los jueces de paz de la Capital y Rosario y en primera instancia las causas civiles mayor a $30 \$$ y hasta la cantidad de 150 \$, los jueces de los cuarteles de Rosario y Santa Fe se ocupaban en primera instancia todas las causas civiles de sus respectivas secciones cuyo valor exceda los 30 \$ hasta la cantidad de $100 \$$. Sus sentencias eran apelables en el término de tres días. En estos casos debían entregar una boleta para que la parte que se entendiese agraviada la presentara ante el Juez de $1 .^{\mathrm{a}}$ Instancia en un término no superior a los cinco días. Además, a diferencia de los jueces de pueblos y colonias, se ocupaban en primera instancia de las demandas criminales sobre injurias y faltas leves, cuyas sentencias podían apelarse ante el Juez de 1 . $^{\text {a }}$ instancia en lo criminal. Para la rea-

como también dar resolución a apelaciones de menos de $6 \$$, y podía valerse del uso de la fuerza en el caso de resistencia de algún delincuente, a una orden.

${ }^{57}$ Reglamento provisorio para los empleados y atribuciones que debe subrogar al Cuerpo municipal, extinguido por ley de 13 de octubre de 1832, 28 enero 1833, ROSF, tomo I: 245-247.

58 Idem.

59 Sobre la expansión del proceso colonizador en Santa Fe: Djenderedjian, Bearzotti y Martiren, 2010. Gallo, 2004. 
lización de estas tareas se les otorgó como emolumento la cantidad de 4 \$ por cada una de las causas que conocieran en primera instancia, debiendo en caso de sentencia pagarlo la parte condenada, y en caso de avenimiento o transacción, por mitad, aunque no podía percibir honorarios en causas que intervinieran en segunda instancia ${ }^{60}$.

En este nuevo Reglamento no se contempló la figura de los Tenientes Jueces, aunque si aparecen en el escalón más bajo del esquema judicial los alcaldes de barrio a quien se los menciona como «auxiliares del juez de paz de la sección á que pertenezcan, para el desempeño de sus funciones» ${ }^{61}$. Estos debían conocer en lo civil y de forma verbal todas las causas de sus respectivas secciones que no excedieran los $30 \$ \mathrm{y}$, en caso de apelación, elevarlas ante el juez de paz, quien conocía estas causas en segunda y última instancia. Su principal tarea principal era conciliar a las partes amigablemente ${ }^{62}$.

La nueva reforma de la Constitución provincial (1863) dejó de lado, una vez más, la reglamentación de las atribuciones judiciales y sólo se limitó a señalar que una futura ley especial reglamentaría y deslindaría las atribuciones de todos los tribunales ${ }^{63}$. Así, unos meses más tarde, se aprobó un nuevo esquema para la organización de la administración de justicia donde la figura de los alcaldes de barrio desaparece y se establece para las ciudades de Rosario y de Santa Fe seis jueces de paz y seis tenientes jueces. Al tiempo que, para los pueblos de San Gerónimo, San José, Villa Constitución, San Lorenzo y las colonias de Esperanza, San Carlos y San Gerónimo se designa un juez de paz y un teniente juez ${ }^{64}$. Sin embargo, las competencias de estos funcionarios de justicia continuaron según lo establecido por el Reglamento de Justicia de 1861.

Un año más tarde un nuevo decreto sobre el Poder Judicial modificó las injerencias de los jueces de paz y tenientes jueces. Este reglamento es el primero que iguala las competencias de los jueces de paz de toda la provincia. Estableció que todos conocerían verbalmente en primera instancia de toda causa civil y mercantil ocurrida en sus respectivos cuarteles o distritos siempre que no excedieran la cantidad de 100 \$ ni sea menor a 30 \$. Debían oír

${ }^{60}$ Reglamento de Justicia, 19 de enero de 1861, ROSF, tomo III: 215.

${ }^{61}$ Ibidem: 216-217.

${ }^{62}$ Sobre los alcaldes de barrio en Santa Fe, véase Barriera, 2017b; 2018: 129-162.

63 Tanto en la sanción de la Constitución provincial (1849) como su posterior reforma (1856) se limitaron a señalar que la organización judicial se abordaría en decretos posteriores. Sobre la reforma constitucional de 1863. Constitución de la provincia de Santa Fe, 12 de febrero de 1863, ROSF, tomo IV: 24.

${ }^{64}$ Ley organizando la Administración de justicia, 21 de mayo de 1863, ROSF, tomo IV: 40. 
y resolver en primera instancia y verbalmente, las demandas por injurias o delitos leves, con facultad de imponer multas proporcionalmente hasta la cantidad de $15 \$$ o arrestos no mayores a cinco días, pero no ambas. Conocerían en grado de apelación y verbalmente, las causas elevadas por los tenientes jueces, quienes se encargaban de causas que no excedían los $30 \$$. Además, estaban autorizados a perseguir, aprehender y remitir a la autoridad competente, a quienes consideraran criminales en sus respectivas secciones o distritos ${ }^{65}$.

Las tareas de los jueces de paz no se agotaban en lo judicial. Además de ser funcionarios menores de justicia, desempeñaron tareas como auxiliares de policía. En el desempeño de las funciones policiales, la ciudad de Rosario contaba con un Jefe de policía - ya no juez de policía-. Este se convirtió en la cabeza del departamento integrado por un Oficial $1 .^{\circ}$, un auxiliar, un médico de policía, los comisarios de diferentes ramos (de mercado, de tablada (encargados del control y traslado del ganado), etc.) y un conjunto de cuerpos inferiores: serenos y piquete de vigilantes ${ }^{66}$. Bajo sus órdenes no sólo se hallaban los comisarios de sección de la ciudad y los comisarios de los diferentes distritos de la campaña, sino que también respondían los jueces de paz. Las tareas que debían llevar adelante la policía eran múltiples: se encargaban del orden y la seguridad pública, del aseo y embellecimiento de la ciudad, de garantizar el alumbrado de las calles, de mantener los cementerios, de apagar incendios y de levantar censos. Se les adjudicó el cobro de algunos impuestos denominados «eventuales de la policía» y la gestión de su propia caja, razón por la cual debían llevar un libro mayor donde anotaban las entradas y salidas de la misma ${ }^{67}$.

La creación de una jefatura de policía y la conformación del Juzgado de 1ra Instancia no significó el deslinde de las funciones de policía y de justicia. Tanto los jueces de paz en la ciudad como los comisarios de distrito en la campaña encarnaban la tradicional indivisión de atribuciones ${ }^{68}$. La concentración de funciones en manos de estos jueces muestra hasta qué

${ }^{65}$ Ley organizando el Poder Judicial, 21 de julio de 1864, ROSF, tomo IV: 179-180.

${ }^{66}$ El 4 de septiembre de 1854 empieza a dar el servicio de policía y cárcel, un piquete de línea en sustitución de la guardia nacional. Carrasco, 1881: 308. Por el impulso dado desde la jefatura política de Rosario se estableció el servicio de guardianes nocturnos o «serenos» sin permiso del gobierno provincial. Esta decisión enfrentó a la jefatura con el gobierno provincial, aunque este acabó aprobando su funcionamiento. Cuerpo de serenos, $1^{\circ}$ de junio de 1855, AHPJM, Jefatura Policía, tomo $1855 \mathrm{C}$, n. ${ }^{\circ} 10$, s/f.

${ }^{67}$ Jefatura de policía, 2 de noviembre de 1855, AHPJM, Jefatura Política, tomo 1855 C, n. ${ }^{\circ} 15, \mathrm{~s} / \mathrm{f}$.

${ }^{68}$ Veáse Bonaudo, 2005: 215-240. 
punto las imbricaciones entre justicia y policía pervivieron hasta avanzada la segunda mitad del siglo XIX ${ }^{69}$. El Reglamento de policía para el departamento de Rosario (1860) dictaminó un conjunto de normas para regular la vida cotidiana tales como la prohibición del uso de cuchillo en la calles y lugares públicos, el juego de envite o azar, el uso de palabras obscenas, blasfemias o expresiones que ofendan la moral, la compra y venta de animales o cueros sin certificaciones de la policía; la limpieza de la ciudad; el control y la remisión de vagos y perjudiciales; la inspección de las pulperías, etc. Sin embargo, el cumplimiento de esta normativa se dejó en manos de «los jueces de paz, alcaldes y tenientes alcaldes en la ciudad» —no los comisarios de cuartel- mientras que en la campaña eran los comisarios de distrito quienes se ocupaban de estas tareas. De igual forma el Reglamento de Policía de ciudad y de campaña (1864) decretó en su artículo $1^{\circ}$ :

Las funciones policiales serán ejercidas por un Geje en la capital y un oficial $1^{\circ}$, bajo la inmediata dependencia del Geje Político en la ciudad de Rosario, un juez de paz en cada una de las ciudades cabeza del Departamento, Comisarios, Jueces y Tenientes Jueces para los cuarteles de las mismas, un comisario general para la campaña de cada Departamento y Comisarios subalternos en los diversos distritos, debiendo cada uno de estos funcionarios, como agentes de Policía, dar cuenta de sus actos al que les preceda en órden gerárquico... ${ }^{70}$

Ahora bien, ¿qué tareas podían desempeñar los jueces de paz? Los cambios institucionales no siempre se acompañaron de modificaciones legislativas. Frente a la falta de una normativa sobre la esfera de acción de estos jueces, muchas de las respuestas se formularon mediante resoluciones elaboradas a nivel local ${ }^{71}$. La práctica de creación de reglamentos ${ }^{72}$ no era novedosa. Por lo contrario, brindaba el marco legal para que los jefes políticos de los departamentos, los jueces de paz y los comisarios de los distritos de cam-

${ }^{69}$ Yangilevich en su estudio muestra el intento del gobierno de Buenos Aires de separar las funciones policiales con la creación de las comisarías y las prefecturas de la campaña. Se trató de una situación efímera, ya que solo funcionaron dos años. La ley fue derogada en 1859 y las funciones de las comisarias volvieron a manos de los jueces de paz. Yangilevich, 2010: 129-153. Véase también: Sedeillán, 2005: 403-422.

70 Reglamento de policía, 9 de agosto de 1864, ROSF, tomo IV: 210.

${ }^{71}$ Un análisis al respecto en Agüero, 2011: 1-43.

72 El término «reglamento» remite a la tradición colonial del derecho indiano que designaba aquellas regulaciones generales de un organismo, de una oficina o una materia determinada. Por lo tanto, su uso en sociedades que gozaban de potestad legislativa y división de poderes y constituciones muestra que la demarcación entre potestades legislativas, judiciales y ejecutivas era todavía muy incipiente. Véase, Garriga, 2007: 169-258. 
paña desempeñaran sus tareas, permitiendo a estas autoridades reforzar su poder para intervenir y decidir sobre la vida de los que poblaban estos territorios y garantizar el orden social ${ }^{73}$. Los edictos fueron una fabricación del derecho de policía que operaba a ras de suelo, una forma de ordenar ciertos aspectos que afectaba la vida cotidiana de la comunidad ${ }^{74}$.

La Jefatura Política hizo circular entre los jueces de paz un reglamento denominado Instrucciones políticas para los jueces de paz mediante el cual se diagramaron un conjunto de funciones que estos debían cumplir en sus cuarteles. Fueron autorizados a ejecutar edictos policiales, aplicar multar y todo lo estipulado en el Reglamento de Policía, es decir se ocupaban de las mismas tareas que los comisarios de sección, ya que se consideró que la superposición de funciones podía realizarse «sin perjuicio de las operaciones...». Se les otorgaron los sellos para el cobro multas, el papel para realizar las certificaciones y la entrega de recibos, debiendo cada quince días presentar una relación detallada de dichos movimientos ${ }^{75}$. También cumplieron con otras funciones de policía, en el sentido antiguo del término: se ocuparon del aseo, la limpieza, la iluminación de las calles y la recaudación de ciertos impuestos ${ }^{76}$. Al igual que los comisarios en los distritos de la campaña, estuvieron a cargo de la elaboración de los registros de la contribución directa y de las patentes de negocios, la entrega de marcas y guías, el control de pesos y medidas, y la realización de los primeros registros estadísticos. En 1854, a petición del Jefe Político, confeccionaron planillas sobre comerciantes, tenderos, almaceneros y demás negocios de la ciudad ${ }^{77}$. Los motivos no eran sólo descriptivos, sino también fiscales ya que la necesidad de sancionar nuevos impuestos requería de la recolección de datos precisos ${ }^{78}$. Igualmente formaron las planillas sobre las edificaciones, sus ocupantes y el número de puertas a

${ }^{73}$ El 18 de marzo de 1855 se dictan las Instrucciones sobre los vagos y malentretenidos y el rol de los comisarios de la campaña y comisarios de distrito, AHPJM, Jefatura Política, tomo $1855 \mathrm{~A}, \mathrm{n}^{\circ}$ 3, s/f. Casi al mismo momento, el 24 marzo de 1855, se sancionó el Reglamento de policía para el pueblo y departamento de Rosario, AHPJM, Jefatura Política, tomo $1855 \mathrm{~A}$, n. $^{\circ} 3, \mathrm{~s} / \mathrm{f}$. Y el 29 mayo de 1855 se aprueban las Instrucciones que deben servir a los comisarios generales de campaña, interin se sanciona el reglamento general de Policía, AHPJM, Jefatura política, tomo $1855 \mathrm{C}, \mathrm{n} .^{\circ} 13, \mathrm{~s} / \mathrm{f}$.

${ }^{74}$ Véase Galeano, 2016: 12-43.

${ }^{75}$ Instrucciones de politica por los jueces de paz, AHPJM, Jefatura Política, tomo 1858 A, n. ${ }^{\circ}$ 9, s/f.

${ }^{76}$ Sobre la función económica de la policía, véase Zamora, 2018: 47-72.

77 Jefatura política, 14 de octubre de 1854, AHPJM, Jefatura política, tomo único, n. ${ }^{\circ} 12$, s/f.

78 De los Ríos, 2017: 165-166. 
la calle de cada cuartel, un dato central para la recaudación, por ejemplo, del impuesto al alumbrado público ${ }^{79}$.

Durante los años sesenta, con la creación de nuevos reglamentos de policía que operaron a nivel provincial se reconocieron como funciones propias de la justicia de paz muchas de las obligaciones estipuladas en las instrucciones locales. El Reglamento de policía urbana y rural (1864) definió a estos jueces como «la policía correccional en la ciudad». Además de sus muchas obligaciones, se ocuparían entonces de castigar la embriaguez, el juego escandaloso, de perseguir las infracciones de las ordenanzas policiales por medio de multas pecuniarias de 1 a 25 \$, prisión correccional o trabajo personal de 1 a 8 días $^{80}$.

\section{LA CREACIÓN DE LA MUNICIPALIDAD Y EL NUEVO ROL DE LOS JUECES DE PAZ}

La Constitución Nacional (1853) estableció la organización política tripartita: nación, provincia y municipios ${ }^{81}$. Al igual que las restantes provincias que integraron la Confederación Argentina, Santa Fe reformó su Constitución provincial (1856) siguiendo los lineamientos del estado central e incluyó por primera vez el Régimen Municipal (capítulo VIII). Sobre municipalidades no se realizaron mayores precisiones que las que contemplaban su pronta formación sin mayores añadidos ${ }^{82}$. Dos años más tarde, se creó el primer reglamento de municipalidad cuyo objetivo era la formación de un cuerpo municipal en Rosario. El proyecto de ley fue elevado a consideración de la Legislatura provincial por el Dr. José Amenábar bajo la premisa de que era urgente la formación de un municipio para la administración de la ciudad ${ }^{83}$. Para su consideración, se designó entonces una Comisión compuesta de Pascual Rosas, Estanislao López y Álvaro de Alsogaray quienes tuvieron la tarea de considerar el proyecto y proponer los

79 Jueces de paz de ciudad, 5 de febrero de 1854, AHPJM, Jefatura política, tomo único, n. ${ }^{\circ} 16: \mathrm{s} / \mathrm{f}$.

${ }^{80}$ Reglamento de policía, 9 de agosto de 1864, ROSF, tomo IV: 210.

${ }^{81}$ A mediados del siglo XIX, el debate en torno a la municipalidad estuvo presente no sólo en otros espacios de la Argentina, sino también en diferentes países latinoamericanos. Sobre este tema puede consultarse Ternavasio, 1991.

82 Constitución provincial de Santa Fe, Registro Oficial de la Nación Argentina, Buenos Aires, (RONA), tomo III: 372.

${ }_{83}$ Proyecto de Ley para la creación de una municipalidad de Rosario, 8 de octubre de 1858, ALP, Cámara de Diputados, tomo IV: 310-314. 
cambios que considerasen necesarios ${ }^{84}$. Luego de su estudio, dicha Comisión resolvió aceptar el proyecto con pocas modificaciones. Una primera enmienda era de orden fiscal y limitaba la composición de las rentas que quedarían en manos de la municipalidad. La segunda cuestión era de orden político y representó un cambio sustancial: el proyecto original establecía que la municipalidad se compondría de once municipales y un presidente elegido por ella, más tres suplentes. Sin embargo, se modificó el artículo dejando como cabeza del cuerpo municipal al Jefe político de Rosario. De esta forma, el número de municipales se redujo a diez más tres suplentes. No se trató de una decisión menor, ya que el Jefe Político era nombrado por el gobernador, es decir designado por decisión del Poder Ejecutivo de la provincia, lo que significaba que la municipalidad quedaba también de alguna forma bajo el control provincial ${ }^{85}$.

En 1860 se instaló el cuerpo municipal dividido en un Consejo de Gobierno - formado por el presidente, dos miembros de la municipalidad y el secretario - y tres comisiones (Comisión de Seguridad, Higiene y educación; Comisión de obras públicas y Comisión de Hacienda). Esta institución asumió diversas tareas que eran desempeñadas por la Policía - a saber la seguridad de los habitantes, el régimen de cárceles y la creación de asilo, la recaudación de las rentas municipales, el control de pesos y medidas, la limpieza de las calles y lugares públicos, la higiene- ${ }^{86}$. Como observa Diego Galeano para Buenos Aires, la creación del poder municipal significó una reducción directa de las prerrogativas policiales en el gobierno de la ciudad ${ }^{87}$. La disputa entre policía y municipio tenía raíces profundas. Hasta bien entrado el siglo XIX, en la mayor parte de Europa los municipios eran generalmente responsables de sus propios mecanismos policiales ${ }^{88}$. En Rosario, se buscó resolver la constante pugna entre municipios y policía con la supresión del cargo de Jefe de Policía, por lo tanto el jefe Político como cabeza del departamento y de presidente de la municipalidad se encargó de la inspección y dirección del

${ }^{84}$ Dictamen de la Comisión formada para la sanción de la ley municipal de Rosario, 25 de noviembre de 1858, ALP, Cámara de Diputados, tomo IV: 319-321.

${ }^{85}$ Las creaciones de las municipalidades estaban contempladas en la Constitución Provincial de 1856 y establecidas por la Legislatura desde 1858. Ley municipal para la ciudad del Rosario, 20 de diciembre de 1858, ROSF, tomo II: 480. Se estableció finalmente en 1860. Ley municipal para los Departamentos de la provincia, 16 de octubre de 1860, ROSF, tomo III: 158 .

${ }^{86}$ Para un análisis detallado de la institución del municipio en Rosario, véase Roldán, 2011.

87 Galeano, 2016: 13.

88 Véase Emsley, 2011: 21-48. 
departamento, teniendo bajo su mando al Oficial 1ro y a los restantes comisarios $^{89}$.

Si observamos en diagrama 3 es posible notar que una parte importante de las tareas policiales de Rosario quedó en manos de la municipalidad: la limpieza pública, el cuidado de los cementerios, el control del reloj público, los encargados del control de los mercados, de alumbrado público, etc. También se nombraron recaudadores de impuesto (de serenos y de limpieza), distintos comisarios municipales y pasó a órbita municipal el cuerpo de serenos de la ciudad. Además, la Ley municipal para Rosario (1858) establecía que los alcaldes y tenientes de barrio quedaban sujetos a las autoridades municipales. Asumía las facultades policiales y la jurisdicción correccional de la ciudad, dentro de los cuales podían dictar ordenanzas, aplicar multas o fijar infracciones ${ }^{90}$. Sin embargo, no perdieron su lugar como auxiliares de los jueces de paz de los cuarteles, quienes tuvieron la tarea de organizar la policía municipal. Por orden del Jefe Político, designaron a un teniente de alcalde municipal por cada uno de las manzanas que componían su cuartel. Los alcaldes, por su parte, además de supervisar las tareas de los tenientes de alcaldes, se encargaron de inspeccionar las patrullas que velaban por la seguridad de sus cuarteles. Se trataba de partidas integradas por cinco vecinos alistados de forma voluntaria que cada noche patrullaba desde las siete de la tarde hasta la seis de la mañana ${ }^{91}$.

${ }^{89}$ Nota del gobernador Rosendo Fraga al jefe político de Rosario Domingo Palacio, 14 de febrero de 1860, AHPJM, tomo $1860 \mathrm{C}$, n. ${ }^{\circ} 24$, s/f.

${ }^{90}$ Ley municipal para la ciudad del Rosario, 20 de diciembre de 1858, ROSF, tomo II: 480.

${ }_{91}$ Jueces de paz de la ciudad, 2 de julio de 1860, AHPJM, Jefatura Política, tomo 1860 $\mathrm{C}, \mathrm{n} .{ }^{\circ} 29, \mathrm{~s} / \mathrm{f}$. 


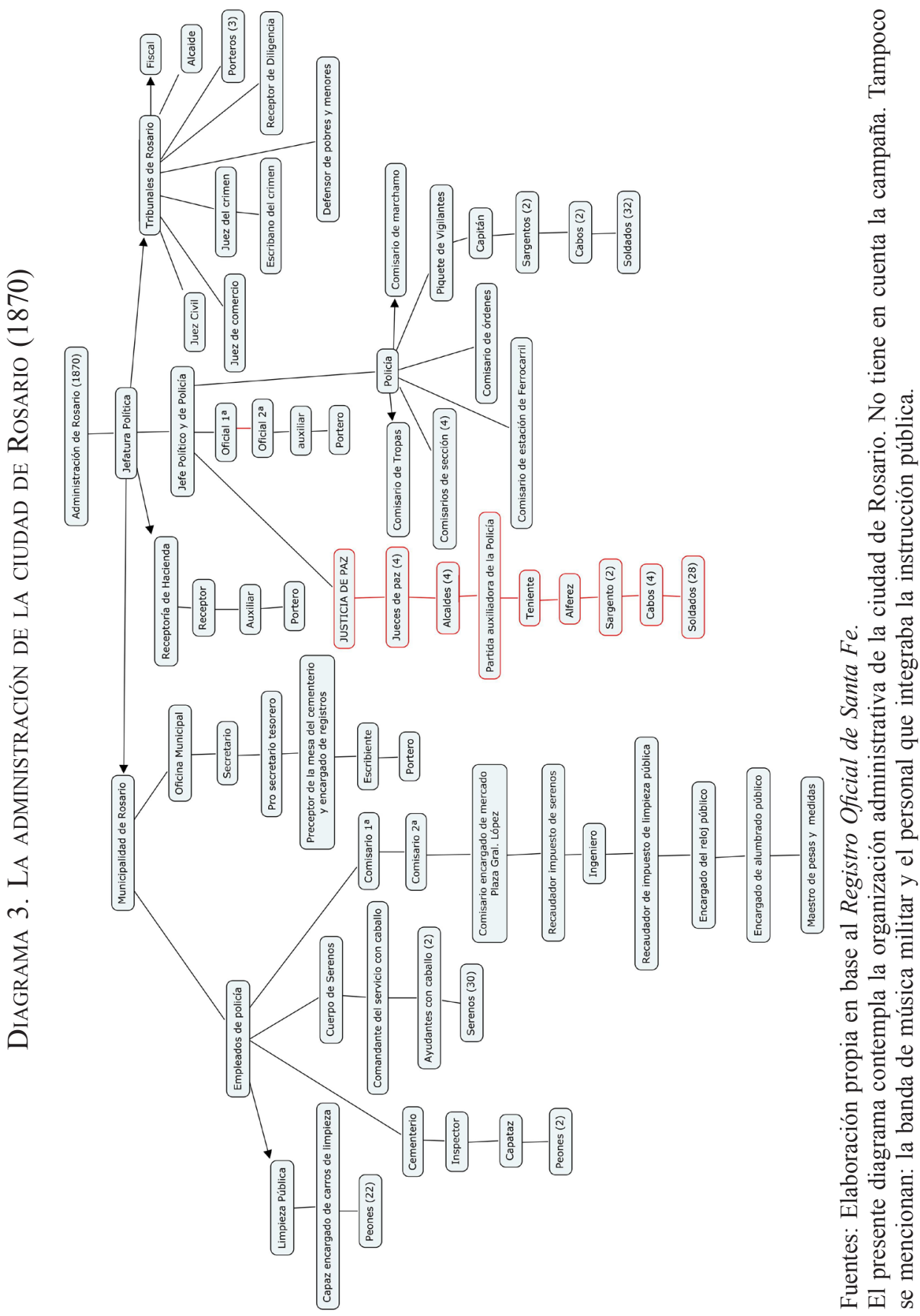




\section{CONCLUSIÓN}

Entre 1850 y 1870 la justicia de paz experimentó profundos cambios. Esta investigación mostró de qué manera los procesos de conformación de la administración local y la incidencia de diferentes proyectos políticos modificaron el esquema de gobierno de la ciudad. La narrativa construida desde el Estado que resalta la conformación de poderes divididos, la construcción de una administración en oficinas, la especialización de saberes y la profesionalización de sus funcionarios ocultan un universo de indefiniciones en los niveles más capilares del tejido social. El abordaje de la justicia de paz amerita realizar algunas precisiones. En primer lugar, bajo el rótulo juez de paz existían un conjunto de funcionarios cuyas funciones, competencias y prácticas variaban de un lugar a otro de la provincia. Los mismos reglamentos de justicia contemplaban diferentes funciones para los jueces de paz de las ciudades de Rosario y Santa Fe, los de San Lorenzo, los de las colonias y pueblos. En segundo lugar, en la confección de un nuevo armazón político-institucional para gobernar este territorio caracterizado por la instalación de numerosas instituciones (Jefatura Política, Jefatura de policía, municipalidad y juzgado), los jueces de paz quedaron sujetos a una triple dependencia, política, policial y judicial, que los convirtió en objeto de conflictos entre la jefatura política, la jefatura de policía y el juzgado. En tercer lugar, en la nueva dinámica de gobierno que se tejió a partir de la instalación de la Jefatura política, los jueces de paz de Rosario vieron reducido su esfera de actuación, pero no así la gama de sus ocupaciones. Estos continuaron cumpliendo funciones judiciales, policiales y fiscales dentro de los límites de sus cuarteles. Un análisis de los diferentes reglamentos de justicia y policía constituye un observatorio propicio para estudiar cómo se fueron definiendo las funciones políticas, judiciales y policiales a nivel local.

Resta aún un largo camino por explorar. Un estudio sistemático de estos funcionarios menores de justicia representa un problema central para componer un cuadro completo de la administración de justicia. Para ello es necesario tomar en cuenta no sólo los cambios institucionales y normativos, sino también reconstruir los vínculos de los jueces de paz con una amplia red de agentes que componían las tramas institucionales que los rodeaban y se tornaban más densas de la mano del crecimiento urbano. El análisis del papel que jugaron estos jueces contribuirá a ampliar los conocimientos sobre la historia política y judicial del período brindando elementos esenciales que permitirán la comparación con otras experiencias. 


\section{BIBLIOGRAFÍA}

Argentina, Primer Censo Nacional de la República Argentina, 1869, Buenos Aires, Imprenta El Porvenir, 1872.

Agüero, Alejandro, "Tradición jurídica y derecho local en una época constitucional. El «Reglamento para la administración de justicia y policía en la campaña» de Córdoba, 1856", Revista de Historia del Derecho, 41 (Buenos Aires, 2011): 1-43.

Agüero, Alejandro, "La extinción del cabildo en la República de Córdoba, 18151824", Boletín del Instituto de Historia Argentina y Americana Dr. Emilio Ravignani, tercera serie/37 (Buenos Aires, 2012): 43-84.

Aliatta, Fernando, "Cultura urbana y organización del territorio", Noemí Goldman (dir.), Nueva Historia Argentina, Tomo III, Revolución, República y Confederación (1806-1852), Buenos Aires, Sudamericana, 1998: 199-254.

Álvarez, Juan, Historia de Rosario (1689-1939), Rosario, UNR Editora, 1998.

Banzato, Guillermo y Valencia, Marta, "Los jueces de paz y la tierra en la frontera bonaerense, 1820-1885”, Anuario del IEHS, 20 (Tandil, 2005): 211-237.

Barreneche, Osvaldo, Dentro de la ley, todo. La justicia criminal de Buenos Aires en la etapa formativa del sistema penal moderno de la Argentina, La Plata, Al Margen, 2001.

Barriera, Darío G., "Un rostro local de la monarquía hispánica: justicia y equipamiento político del territorio al sureste de Charcas, siglos XVI y XVII", CLAHR, Colonial Latin American Historical Review, 15/4 (Albuquerque, 2006): 377-418.

Barriera, Darío G., Instituciones, gobierno y territorio. Rosario de la Capilla al municipio (1725-1930), Rosario, ISHIR / CONICET, 2010a.

Barriera, Darío G., "Justicias, jueces y culturas jurídicas en el siglo XIX rioplatense", Nuevo mundo Mundos nuevos (Francia, 2010b): s/p.

Barriera, Darío G., "Rediseñando lo judicial, reinventando lo jurídico: el reglamento de 1833 y los orígenes de la justicia de paz en la provincia de Santa Fe", Valentina Ayrolo (coord.), Actas de las IV Jornadas de Trabajo y Discusión sobre el siglo XIX Las Provincias en la Nación, Grupo de Investigación "Problemas y Debates del siglo XIX”, Mar del Plata, CEHiS / FH-UNMDP / CBediciones, 2011: 213-226.

Barriera, Darío G., "Justicia de proximidad: pasado y presente, entre la historia y el derecho", PolHis, Boletín Bibliográfico electrónico del Programa Buenos Aires de Historia Política, 5/10 (Buenos Aires, 2012a): 50-57.

Barriera, Darío G., "Instituciones, justicias de proximidad y derecho local en un contexto reformista: designación y regulación de jueces de campo en Santa Fe (Gobernación Intendencia de Buenos Aires) a fines del siglo XVIII", Revista de Historia del Derecho, 44 (Buenos Aires, 2012b): 1-28. 
Barriera, Darío G., "Justicias rurales: el oficio de alcalde de la Hermandad entre el derecho, la historia y la historiografía (Santa Fe, Gobernación del Río de la Plata, siglos XVII a XIX)", Andes, 25 (Salta, 2013a): 1-31.

Barriera, Darío G., "La organización del territorio y su gobierno: alcaldes mayores para la villa del Rosario. Un capítulo de transición (1826-1832)", Revista de la Junta Provincial de Estudios Históricos de Santa Fe, 70 (Santa Fe, 2013b): 137-167.

Barriera, Darío G., "La dimensión política de un acontecimiento jurídico. Tras los orígenes de justicia de paz en la provincia de Santa Fe (1833)", María Sierra, Juan Pro, Juan Mauro y Diego Mauro (eds.), Desde la historia. Homenaje a Marta Bonaudo, Buenos Aires, Imago Mundi, 2014: 235-252.

Barriera, Darío G., "La supresión del cabildo y la creación de los juzgados de paz: dimensión provincial de la justicia de equidad en el litoral rioplatense (Santa Fe, 1833)", Elisa Caselli (coord.), Justicia, agentes y jurisdicciones. De la Monarquía Hispánica a los Estados Nacionales (España y América, siglos XVI y XIX), Madrid, FCE / Red Columnaria, 2016: 427-450.

Barriera, Darío G., "La justicia de paz en la provincia de Santa Fe (1833-1854): justicia de proximidad, justicia de transición", Macarena Cordero, Rafael Gaune y Rodrigo Moreno (comps.), Cultura legal y espacios de justicia en América, siglos XVI-XIX, Chile, Universidad Adolfo Ibáñez, 2017a: 289-312.

Barriera, Darío G., "El alcalde de barrio, de justicia a policía (Río de la Plata, 17701830)", Nuevo Mundo Mundos Nuevos, (Francia, 2017b): s/p.

Barriera, Darío G., "Y en el principio, fue la justicia. Las alcaldías de barrio: visibilización de un desenredo en la cultura jurisdiccional (De justicia a policía y nuevamente a justicia: 1772-1861)", Darío G. Barriera (dir.), Justicias situadas: Instituciones, agentes, cultura y espacios (entre el Virreinato rioplatense y la República Argentina, 1776-1864), La Plata, Universidad Nacional de La Plata / FaHCE, 2018: 129-162.

Beraldi, Nicolás, "La implementación de la justicia de paz en la provincia de Córdoba. ¿Claves liberales en un mundo tradicional? (1855-1883)", Revista de Historia del Derecho, 53 (Buenos Aires, 2017): 1-22.

Bonaudo, Marta, "Las élites santafesinas entre el control y las garantías: el espacio de la jefatura política", Hilda Sábato, La vida política en la Argentina del siglo XIX. Armas, votos y voces, Buenos Aires, FCE, 2003: 259-276.

Bonaudo, Marta, "Hecho jurídico... hecho político. La conflictiva relación entre poder y justicia en la construcción de la República Posible. Santa Fe, 1856-1890", María Inés Carzolio y Darío G. Barriera (comps.), Política, cultura, religión. Del Antiguo Régimen a la formación de los Estados Nacionales. Homenaje a Reina Pastor, Rosario, Prohistoria Ediciones, 2005: 215-240. 
Bonaudo, Marta (comp.), La Organización productiva y politica del territorio provincia (1853-1912), Tomo 6, Nueva Historia de Santa Fe, Rosario, La Capital / Prohistoria ediciones, 2006.

Bonaudo, Marta, "Aires gaditanos en el mundo rioplatense. La experiencia de los jefes políticos y el juicio por jurados en tierras santafesinas (segunda mitad del siglo XIX)", Revista de Indias, LXVIII/ 242 (Madrid, 2008): 255-280.

Bragoni, Beatriz y Miguez, Eduardo (coords.), Un nuevo orden político. Provincias y Estado nacional, 1852-1880, Buenos Aires, Editorial Biblos, 2010.

Candioti, Magdalena, "Los jueces de la revolución: pertenencia social, trayectorias políticas y saberes expertos de los encargados de hacer justicia en Buenos Aires (1810-1830)", Mónica Alabart, María Alejandra Fernández y Mariana Pérez (comps.) Buenos Aires. Una sociedad que se transforma. Entre la colonia y la revolución de mayo, Buenos Aires, Prometeo / UNGS, 2012: 287-324.

Candioti, Magdalena y Palacio, Juan Manuel, "Justicia, política y derechos en América Latina. Apuntes para un diálogo interdisciplinario", Magdalena Candioti y Juan Manuel Palacio (eds.), Justicia y derechos en América Latina, Buenos Aires, Prometeo Libros, 2007: 11-24.

Canedo, Mariana, "Construyendo el territorio tras Caseros: los jueces de paz y la administración pública en la formación del Estado de Buenos Aires", Antíteses, IV/8 (Londrina, 2011): 675-702.

Carrasco, Eudoro y Carrasco, Gabriel, Anales de la Historia de Rosario de Santa Fe con datos generales sobre Historia Argentina 1527-1865, Buenos Aires, Imprenta Peuser, 1897.

Carrasco, Gabriel, Datos estadístico de la Provincia de Santa Fe, Rosario, Imprenta de Aduana, 1881.

Castillo Hernández, Diego, "La ley y el honor: jueces menores en la ciudad de México, 1846-1850”, Signos Históricos, 13/26 (México, 2011): s/p.

Chiaramonte, Juan Carlos, "El federalismo argentino en la primera mitad del siglo XIX”, M. Marcello Carmagnani, Federalismos latinoamericanos: México/ Brasil/ Argentina, México, FCE, 1993: 81-132.

Cobos Gavala, Rosa, El juez de paz en la organización jurisdiccional española, Madrid, Ministerio de Justicia, 1989.

Corva, María Angélica, "La justicia en la campaña, el rol del juez de paz como sumariante, 1855-1880", Actas del VIII Congreso de Historia de los Pueblos de la Provincia de Buenos Aires, Luján, 8 y 9 de noviembre 2001, Luján, CDRoom.

Cutolo, Vicente, Diccionario Biográfico Argentino, Buenos Aires, Elche, 1968, 8 tomos.

De los Rios, Evangelina, Gobernar es cobrar. Politica fiscal, recaudación impositiva y cultura tributaria. Santa Fe, (Argentina, 1855-1872), Rosario, Prohistoria Ediciones, 2017. 
De los Ríos, Evangelina, "Las oficinas de aduana y resguardo del puerto de Rosario en tiempos de la Confederación Argentina, 1852-1854", América Latina en la Historia Económica, 26/1 (México, 2019): 24-46.

Delaigue, Philippe, "Une justice de proximité: création et installation des juges de paix (1790-1804)", Revue d'Histoire de la justice, 8-9 (París, 1995): 31-47.

Di Gresia, Leandro, "Jueces de paz, masones y conservadores en la campaña bonaerense. Una aproximación a las redes vinculares en el sur de la provincia de Buenos Aires (Tres Arroyos, 1865-1910)", Mundo Agrario: Revista de estudios rurales, 11/21 (Buenos Aires, 2010): s/p.

Djenderedjian, Julio, Bearzotti, Sílcora y Martirén, Juan Luis, Historia del capitalismo agrario pampeano, Tomo 6: Expansión agrícola y colonización en la segunda mitad del siglo XIX, Buenos Aires, Teseo / Editorial Universidad de Belgrano, 2010.

Emsley, Clive, "Los modelos de policía en el siglo XIX", Diego Galeano y Gregorio Kaminsky (coords.), Miradas (de) uniforme. Historia y crítica de la razón policial, Buenos Aires, Teseo, 2011: 21-48.

Ensinck, Oscar, "Jurisdicción y atribuciones de los jueces de paz (1833-1854)", Revista de Historia de Rosario, 3 (Rosario, 1963): 5-25.

Ensinck, Oscar, "El puerto de Rosario y los derechos diferenciales. Principio y fin de una época (1851-1860)", Separata de la Revista de Historia de Rosario, 21-22 (Rosario, 1971): 1-50.

Flori, Thomas, El juez de paz y el jurado en el Brasil imperial, México, FCE, 1986.

Fradkin, Raúl (comp.), El poder y la vara: estudios sobre la justicia y la construcción del Estado en el Buenos Aires rural: 1780-1830, Buenos Aires, Prometeo libros, 2007.

Fradkin, Raúl (comp.), La ley es tela de araña. Ley, justicia y sociedad rural en Buenos Aires, 1780-1830, Buenos Aires, Prometeo Libros, 2009.

Fradkin, Raúl, "Notas para una historia larga: comandantes militares y gobierno local en tiempos guerra", Beatriz Bragoni y Eduardo Míguez (coords.), Un nuevo orden político. Provincias y Estado Nacional, 1852-1880, Buenos Aires, Biblos, 2010: 293-306.

Frid, Carina, "Desigualdad y distribución de la riqueza en escenarios de crecimiento económico: Santa Fe, 1850-1870", Jorge Gelman (coord.), El mapa de la desigualdad en la Argentina del siglo XIX, Rosario, Prohistoria, 2011: 95-138.

Frid, Carina, "Producción agraria y crecimiento económico en el sur de Santa Fe (1840-1860)", Carina Frid y Norma Lanciotti (comps.), De la expansión agraria al desarrollo industrial: la economía de Santa Fe entre 1850 y 1970, Rosario, Prohistoria ediciones, 2012: 17-48. 
Galeano, Diego, "La ley de la policía: edictos y poder contravencional. Ciudad de Buenos Aires, siglo XIX", Revista Historia y Justicia, 6 (Santiago de Chile: 2016): $12-43$.

Gallo, Ezequiel, "Santa Fe en la segunda mitad del siglo XIX. Transformaciones en su estructura regional", Anuario del Instituto de Investigaciones Históricas de la Universidad Nacional del Litoral, 7 (Santa Fe, 1965): 127-161.

Gallo, Ezequiel, La Pampa Gringa. La colonización agrícola en Santa Fe (18701895), Buenos Aires, Edhasa, 2004.

Garavaglia, Juan Carlos, "Paz, orden y trabajo en la campaña: la justicia rural y los juzgados de paz en Buenos Aires, 1830-1852", Desarrollo Económico, 37/146 (Buenos Aires, 1997): 241-262.

Garavaglia, Juan Carlos, Poder, conflicto y relaciones sociales, el Río de la Plata (siglos XVIII-XIX), Rosario, Homo Sapiens, 1999.

Garavaglia, Juan Carlos, La disputa por la construcción nacional argentina. Buenos Aires, la Confederación y las provincias (1850-1865), Buenos Aires, Prometeo Libros, 2016.

Garriga, Carlos, “Constitución, ley, reglamento: el nacimiento de la potestad reglamentaria en España (1810-1814, 1820-1823)", Carlos Garriga y Marta Lorente, Cádiz, 1812. La constitución jurisdiccional, Madrid, Centro de Estudios Políticos y Constitucionales, 2007: 169-258.

Gascón Inchausti, Fernando, "La figura del juez de paz en la organización judicial española", Reforma Judicial. Revista mexicana de justicia, 8 (México, 2006): 183-213.

Gastellu, Sofía, "La Justicia de Paz en la ciudad de Buenos Aires. La dimensión territorial de una justicia de proximidad (1821-1854)", Darío G. Barriera (dir.), Justicias situadas: Instituciones, agentes, cultura y espacios (entre el Virreinato rioplatense y la República Argentina, 1776-1864), La Plata, Universidad Nacional de La Plata / FaHCE, 2018: 263-290.

Gelman, Jorge, "Crisis y reconstrucción del orden en la campaña de Buenos Aires. Estado y sociedad en la primera mitad del siglo XIX", Boletín del Instituto de Historia Argentina y Americana Dr. Emilio Ravignani, tercera serie/21 (Buenos Aires, 2000): 7-31.

Métairie, Guilleume, Monde de juges de paix de Paris, 1790-1838, París, Univ. Lille, 1994.

Métairie, Guillaume, La justice de proximité une approche historique, París, Presses Universitaires France, 2006

Molina, Eugenia, "Justicia de proximidad y gobierno político-militar en la frontera. Equipamiento institucional del Valle de Uco (Mendoza) durante el proceso revolucionario (1810-1820)", Revista Mundo Agrario, 15/30 (La Plata, 2014): s/p. 
Molina, Eugenia y Yangilevich, Melina, "Justicia menor y equipamiento institucional de los espacios urbanos y rurales en Hispanoamérica en el tránsito del Antiguo Régimen al orden republicano, siglo XVII-XIX", PolHis, Boletín Bibliográfico electrónico del Programa Buenos Aires de Historia Política, 50 (Mar del Plata, 2015): s/p.

Moreno, Damián, Los jueces de paz, Madrid, UNED, 1987.

Petit, Jacques-Guy, "La Justice en France, 1789-1939. Une étatisation modèle?", Crime, Histoire \& Sociétés /Crime, History \& Societies, 6/1 (Suiza, 2002): 85-100.

Petit, Jacques-Guy, Une justice de proximité: la justice de paix, París, Presses Universitaires France, 2003.

Piazzi, Carolina, Justicia criminal y cárceles en Rosario: segunda mitad del siglo XIX, Rosario, Prohistoria ediciones, 2011.

Piazzi, Carolina, "Justicia de primera instancia en Santa Fe (Argentina): diseño normativo y jueces entre 1833 y 1854", Americanía, 4 (Sevilla, 2016): 372-399.

Piazzi, Carolina, "Administración y materialidad: una etnografía del Juzgado del Crimen del Rosario (Argentina, segunda mitad del siglo XIX)", Historia Crítica, 63 (Bogotá, 2017a): 53-74.

Piazzi, Carolina, "Gobierno y régimen administrativo departamental: comandancias militares, jefaturas políticas, juzgados y policías (el caso santafesino en la segunda mitad del siglo XIX)", XVI Jornadas Interescuelas Mar del Plata, 9, 10 y 11 de agosto de 2017, Mar del Plata, Universidad de Mar del Plata, 2017b.

Polimene, María Paula, "Jueces santafesinos en la otra banda del Paraná. El problema de la proximidad en el proceso de reordenamiento territorial de la campaña. Pago de Bajada, último cuarto del siglo XVIII", Darío G. Barriera (comp.), Gobierno, justicias y milicias: la frontera entre Buenos Aires y Santa Fe (1720-1830), La Plata, UNLP / FAHCR, 2014: 157-176.

Registro Estadístico de la Población de la Provincia de Santa Fe (Confederación Argentina), Con sujeción al Censo Oficial levantado en abril de 1858 bajo la dirección de Juan José Gormaz y Carreras; copia manuscrita del original auténtico por Gabriel Carrasco. Buenos Aires, s/e, 1900.

Registro Oficial de la provincia de Santa Fe, Santa Fe, Tipografía de la Revolución, 1890.

Registro Oficial de la República Argentina que comprende los documentos expedidos desde 1810 hasta 1873, Tomo III: 1852-1856, Buenos Aires, Imprenta La República, 1879.

Reguera, Andrea y Di Gresia, Leandro, "El poder estructurante de los lazos relacionales: los jueces y la justicia de paz en Argentina: provincia de Buenos Aires, primera mitad del siglo XIX", MÉTIS: história \& cultura, 13/25 (Caxias do Sul, 2014): 103-128. 
Roldán, Diego, "La construcción local de funciones y competencias estatales en la Argentina (Rosario, 1886-1952)", Juan Carlos Garavaglia y Claudia Contente (eds.), Configuraciones estatales, regiones y sociedades locales. América Latina, siglos XIX-XX, Barcelona, Ediciones Bellaterra, 2011: 155-183.

Romano, Silvia, "Instituciones coloniales en contextos republicanos: los jueces de campaña cordobesa en las primeras décadas del siglo XIX y la construcción del estado provincia autónomo", Fabián Herrero (ed.), Revolución, política e ideas en el Río de la Plata durante la década de 1810, Buenos Aires, Ediciones Cooperativas, 2004: 167-200.

Salvatore, Ricardo, Subalternos, derechos y justicia penal. Ensayos de historia social y cultural argentina 1829-1940, Barcelona, Gedisa editorial, 2010.

Sampaio Silva, Patricia, "Jueces de fuera, jueces de la tierra. Justicia y municipalidad a través del estudio de un caso brasileño”, Araucaria. Revista Iberoamericana de Filosofía, política y Humanidades, 9/18 (Sevilla, 2007): 266-285.

Sanjurjo de Driollet, Inés, "La justicia de paz en Mendoza. Leyes de 1872, 1876 y 1880”, Revista Confluencias, 1/2 (Mendoza, 2003): 129-143.

Sanjurjo de Driollet, Inés “Justicia de paz y cultura jurídica en el largo siglo XIX en Mendoza (Argentina). El caso del departamento de San Rafael en el sur provincial", Nuevo mundo Mundos nuevos, (Francia, 2010): s/p.

Sedeillán, Griselda, "La pérdida gradual de las funciones policiales del juzgado de paz: la creación de la institución policial en Tandil 1872-1900", Anuario del Centro de Estudios Históricos Prof. Carlos S. A. Segreti, 5 (Córdoba, 2005): 403-422.

Tedeschi, Sonia, "Los últimos años de una institución colonial: el cabildo de Santa Fe y su relación con otros estaciones políticos-institucionales entre 1819 y 1832 ", Revista de la Junta Provincial de Estudios Históricos de Santa Fe, LIX (Santa $\mathrm{Fe}, 1993): \mathrm{s} / \mathrm{p}$.

Ternavasio, Marcela, Municipio y política, un vínculo histórico conflictivo, tesis de maestría, Buenos Aires, FLACSO, 1991.

Ternavasio, Marcela, "Entre el cabildo colonial y el municipio moderno: los juzgados de paz de campaña en el Estado de Buenos Aires, 1821-1854", Marco Bellingeri (coord.), Dinámicas de Antiguo Régimen y orden constitucional. Representación, justicia y administración. Siglos XVIII-XIX, Torino, Otto editorial, 2000a: 295336.

Ternavasio, Marcela, "La supresión del Cabildo de Buenos Aires. ¿Crónica de una muerte anunciada?", Boletín del Instituto de Historia Argentina y Americana Dr. Emilio Ravignani, 3. ${ }^{\mathrm{a}}$ serie/21 (Buenos Aires, 2000b): 33-73.

Tío Vallejo, Gabriela, "Los historiadores "hacen justicia": un atajo hacia la sociedad y el poder en la campaña rioplatense en la primera mitad del siglo XIX", Revista de Historia del Derecho, 41 (Buenos Aires, 2011): 199-212. 
Tornay, María Laura, "La justicia rural en Santa Fe colonial. Cambios institucionales y sociales en el período borbónico", Actas del IV Encuentro de Historiadores de la Junta Provincial de Estudios Históricos de Santa Fe (2002), Santa Fe, Junta de Estudios Históricos, 2004.

Yangilevich, Melina, "Crónicas de conflicto y desilusión. Prefecturas de campaña, juzgados de paz y comisarías en Buenos Aires (1857-1859)", Darío Barriera (coord.), La Justicia y las formas de autoridad. Organización política y justicias locales en territorios de frontera. El Río de la Plata, Cuyo, Córdoba y el Tucumán, siglos XVIII y XIX), Rosario, Red Columnaria / ISHIR / CONICET, 2010: 129-153.

Yangilevich, Melina, "Justicia de paz y organización del territorio en la campaña sur de Buenos Aires durante la primera mitad del siglo XIX. Un diálogo con Juan Carlos Garavaglia", Revista Prohistoria, 28 (Rosario, 2017): 73-94.

Yangilevich, Melina, "Los jueces letrados de Buenos Aires. Perfiles, trayectorias y vínculos", Darío G. Barriera (dir.), Justicias situadas. Entre el Virreinato rioplatense y la República Argentina (1776-1864), Mar del Plata, UNMdP / FaHce editorial, 2018: 213-242.

Zamora, Romina, "Jurisdicción económica, policía económica, economía política. La función de policía y las justicias menores en el Virreinato del Río de la Plata", Darío G. Barriera (dir.), Justicias situadas: Instituciones, agentes, cultura y espacios (entre el Virreinato rioplatense y la República Argentina, 1776-1864), La Plata, Universidad Nacional de La Plata, FaHCE, 2018: 47-72.

Fecha de recepción: 14 de junio de 2019.

Fecha de aceptación: 18 de noviembre de 2019.

\section{The justice of the peace and transformations in city government (Rosario, 1852-1872)}

The article studies the transformations experienced by the figure of the justice of the peace in Rosario (Santa Fe, Argentina) between 1852 and 1872. It will show that these not only involved changes in regulatory and judicial decisions, but also in the way the city was governed. The research aims to examine the redefinitions of the role of these judges from a reconstruction of the network of relations — political, judicial, police, administrative, etc. - of which they were a part.

KEY WORDS: justice of the peace; government; administration; Rosario; nineteenth century. 